Vesna Stojanović-Aleksić, Aleksandra Bošković ${ }^{1}$ Faculty of Economics, University of Kragujevac

\title{
What Really Drives Corporate Social Responsibility?
}

DOI: 10.7595/management.fon.2017.0018

\begin{abstract}
Corporate social responsibility (CSR) can be motivated either by instrumental, moral or obligatory factors. The paper aims to explore how these motives influence the level of CSR. Specific attention is paid to the CSR in state-owned and private companies, since their motives are significantly different. In order to examine these relationships, an empirical study was conducted on a sample of 80 respondents, employed in 24 companies from several industries in the territory of the Republic of Serbia. The findings indicate that internal CSR is more developed if moral motives are dominant. Also, CSR in general, internal CSR and responsibility to customers, are higher in state-owned companies, compared to the private ones. The contribution of the paper is reflected in the discovery of new insights, which are the basis for future research, but also useful for directing the activities of management in the field of CSR which is one of the key requirements for sustainable business.
\end{abstract}

Keywords: Corporate social responsibility, motives, ethics, performance, obligation, state ownership, Serbia.

\section{Introduction}

The stakeholder theory (Freeman, 1984) suggests that each corporation is a social institution that bears responsibility, not only towards shareholders, but towards other interest groups as well. A corporation is an integral part of the society and besides economic objectives, its impact on the internal and external environment must be taken into account. Significant research efforts have been made in the area of corporate social responsibility (CSR) (Lopatta, Jaeschke, Chen, 2017; Dare, 2016; Brunton, Eweje \& Taskin, 2015; Pérez \& Rodríguez del Bosque, 2015; Martínez \& Rodríguez del Bosque, 2013; Devinney, 2009; Aguilera, Rupp, Williams, \& Ganapathi, 2007; Porter \& Kramer, 2006; Kotter \& Lee, 2005; Garriga \& Mele, 2004; Carroll, 1999; Davis, 1967; Bowen, 1953), but there are still many dilemmas about the nature and the scope of this concept, both in scientific and professional communities.

One of the current issues concerns the real reasons for companies to act in a socially responsible manner. Is it ethics, philanthropy, or is it just a cover for the achievement of some other, primarily financial or market objectives? Devinney (2009) believes that an enterprise cannot be truly socially responsible, even in the narrowest sense and that the concept of CSR is an oxymoron, because companies must balance between different interests, which are conflicting by their nature and it is naive to believe that their activities are designed according to the requirements of the society. Companies actually manipulate social interests, in order to achieve their own goals. The author presents a rather extreme position, believing that the paradigm do-well-by-doing-good reflects an unrealistic goal, a noble idea, which is infeasible in practice.

Other authors provide empirical evidence on the multiple benefits of CSR, such as the improvement of competitive advantage (Porter \& Kramer, 2006) or employee satisfaction (Koh \& Boo, 2004). Although the 
impact of social responsibility on the financial performance is difficult to measure, and previous studies lead to conflicting results (Surroca, Tribo, \& Waddock, 2010; McWilliams \& Siegel, 2000), it is possible to identify a specific positive relationship (Margolis, Elfenbein, \& Walsh, 2007; Stankevicienë \& Cepulytë, 2014). However, the real effects are indirect and can only be expected in a long term. Also, if irresponsible behaviour finds the public condemnation, it causes high losses, which are then difficult to compensate. Accordingly, the potential positive effects, even in a very long period, are far more profitable than any damage. All these reasons may be motives for CSR.

Compared to the growing body of literature on the nature and consequences of CSR, the issue of which factors determine the CSR level, has received relatively limited attention. Previous studies have dealt with CSR motives (Dare, 2016; Petrenko, Aime, Ridge, \& Hill, 2016; Aguilera, Williams, Conley, \& Rupp, 2006; Munilla \& Miles, 2005), but there is a lack of empirical evidence on their connection to the level of CSR development, particularly in terms of the internal and external dimensions. Thus, this paper is driven by an aspiration to overcome this perceived gap. Namely, it is necessary to further investigate the underlying factors that motivate management to take initiatives in this area, since it affects the course and the level of CSR.

There are different factors that determine both CSR motives and the level of CSR, one of which is the ownership type (Dam \& Scholtens, 2012; Oh, Chang, \& Martynov, 2011). For decades, public and privatelyheld corporations have shown varying levels or degrees of commitment to CSR (Dare, 2016). The state as owner may be more prone to invest in CSR, since one of the main goals of each government is the fulfilment of public interest. In addition, state-owned companies are more exposed to the public eye, so this can be a reason to engage in socially responsible activities (Mohd Ghazali, 2007, p.255). However, there is also a high level of CSR in private companies who strive to improve clients' trust and their own corporate image (Pérez \& Rodríguez del Bosque, 2015). Due to the heterogeneity of existing evidence, the relationship between state ownership and CSR should be further explored.

According to the subject determined, the basic aim of the research is to determine the extent to which differences in the level of CSR occur as a result of differences in terms of the key CSR motives. Specific goals are to explore how the underlying factors that motivate management to undertake CSR activities determine the level of internal and external social responsibility, as well as to find out if CSR is affected by ownership type, particularly taking into consideration state and private ownership.

\section{Literature Review and Hypotheses Development}

Attempts to define corporate social responsibility began in the mid-twentieth century, but even today there is no universally accepted definition. Carroll (1999) gave a remarkable contribution to the literature in the field of CSR by tracing the evolution of the definitional construct, from 1950s to 1990s. This period is characterized by significant differences in attitudes on the meaning and the validity of the concept. Initial definitions explain social responsibility as an obligation to act in compliance with the values of society (Bowen, 1953). However, modern approaches emphasize the voluntary nature of CSR (Carroll, 1991; European Commission, 2011, p.3), referring to the activities that cross the border of law and are based on altruism or philanthropy. The company should be responsible to its internal and external environment, i.e., to all the stakeholders, such as employees (internal CSR), business partners, suppliers, customers, governments, non-governmental organizations who represent the interests of local communities and the environment (Stojanovic-Aleksic \& Boskovic, 2015; Commission of the European Communities, 2001; Hawn \& loannou, 2016; Skudiene \& Auruskeviciene, 2012). In addition to internal and external dimensions, CSR disclosure represents a significant area of responsibility. In contemporary literature, much attention has been paid to this issue, especially in recent years when information is more accessible, since companies pay more attention to publishing data on their environmental and accountability activities towards employees, clients and the community (Gray, Kouhy, \& Lavers, 1995; Kuo, Yeh, \& Yu, 2012). But above all, a company must be able to make a profit that allows a sustainable competitive position. In order to achieve this, CSR must be effectively managed and supported by adequate organizational structures (Vlastelica Bakic, Cicvaric Kostic, \& Neskovic, 2015).

Representatives of the free market theory, such as Friedman (1962), explicitly state that there is no other purpose of corporate social responsibility than to make as much money for stockholders as possible (Carroll, 1999, p. 277). However, the link between CSR and financial performance is difficult to measure and remains 
unclear. A group of authors conducted a meta-analysis that included 192 studies on the above relationship, and a survey showed the existence of a positive, statistically significant but small effect (Margolis et al., 2007). Another study has shown that CSR has a positive effect on value creation (Stankevicienë \& Cepulytë, 2014). Still, the difficulties in quantifying this interdependence are primarily reflected in the fact that the financial effects of social responsibility are difficult to measure in the short term, and that this area of business, by creation of intangible resources, has many positive implications in the long term. An organization directly or indirectly generates a series of benefits through CSR, including: strengthening the brand, improving the image (Virvilaite \& Daubaraite, 2011) and the ability to attract, motivate and retain employees and consumers (Kotter \& Lee, 2005, p.12), which in the long run leads to the reduction in operating costs and improvement of their competitive position (Porter \& Kramer, 2006). In addition, studies have shown that involvement in socially desirable activities leads to greater employee satisfaction (Koh \& Boo, 2004) and subsequently their positive emotions (Onkila, 2015). Therefore, social responsibility can play an important role in retaining existing human resources, but also in attracting new high-quality workers, since it can portray the perception of the company's organizational culture as being friendly and humane. Also, CSR disclosure may be encouraged by state subsidies in some countries, e.g., China (Lee, Walker, \& Zeng, 2017). All of these motives, directly or indirectly related to reaching certain benefits by engagement in CSR, can be labelled as instrumental (Aguilera et al. 2006).

On the other hand, motives can stem from the tendency to conform with emerging industry norms and standards (Aguilera et al., 2006) or can be seen as a "tax" being mandated by NGOs or other stakeholders (Munilla \& Miles, 2005). We consider these factors as obligatory motives for CSR. This group of motives includes different social and political, i.e., legal and regulatory drivers (Stjepcevic \& Siksnelyte, 2017), such as laws or quality standards.

In addition, according to Gibson (2000), corporations actually have a moral responsibility to all the stakeholders. Hence, there are managers, encouraged by moral motives, who engage in CSR due to a higher purpose to help humanity.

Dare (2016) analyzed the impact of different motives on CSR commitment and proved that firms with dominant moral motive tend to hold a higher commitment to CSR than firms with a dominant instrumental motive. On the other hand, Munilla and Miles (2005) suggest that strategic motives, referring to CSR as an investment in improving operations, can positively affect employees' contribution to creating added value for customers and the local community, while CSR as forced obligation may lead to the alienation of certain groups of customers. Zhu and Zhang (2005), on the other hand, have separated CSR drivers into internal and external, with internal ones being related to governance and organizational structures, as well as a value systems on individual, group and organizational levels, while external drivers include normative, coercive and mimetic (competitive) factors. They found that Chinese state-owned companies have high internal CSR values which promote most CSRs except those related to charity and employee rights. External institutional drivers for CSR practices are relatively low. Normative drivers motivate most CSR practices while competitive drivers only motivate consumer issues-related CSR practices. A study conducted in Serbia by Curcic, Miletic \& Bjegovic (2016) has shown that companies are mainly emphasizing performance-driven motives for CSR, but there is no data on how this affects the level of certain CSR areas in Serbia.

Starting from the theoretical foundations and the results of previous empirical studies, which show that CSR motives are in correlation with the level of CSR (Dare, 2016; Munilla \& Miles, 2005), we occupy a relatively different perspective on the problem aiming to find out which specific CSR aspects vary depending on the dominant CSR motives. We believe that companies, whose management is encouraged by moral motives (a tendency to increase employee satisfaction and the other motives of moral or ethical character), should have a higher level of internal CSR, i.e., concern for the welfare of employees. Hence, the first hypothesis is:

H1: The level of internal CSR will be higher if the motives are moral.

Instrumental motives, based on the principle of utility, can result in a greater involvement of a company in all aspects of external CSR, since activities, such as humanitarian actions, activities with the aim of contributing to culture, sports, environmental protection and publication of information about CSR, are often widely promoted and can directly affect financial results. Therefore, we hypothesize:

H2: The level of external CSR will be higher if the motives are instrumental. 
Finally, the paper starts from the assumption that obligatory motives indicate an underdeveloped awareness of the importance of CSR and can have a negative impact both on internal and on external social responsibility. Thus, the third hypothesis is:

H3: The level of CSR will be lower if motives are solely obligatory.

In addition to the aforementioned motives, it can be argued that there is a link between ownership and the motivation for CSR (Dam \& Scholtens 2013; Oh et al., 2011; Fernandez Sanchez, Sotorrio \& Diez 2011; Aguilera et al., 2006). Recent studies have shown that state ownership companies show significant engagement in CSR (Cordoba-Pachon, Garde-Sanchez, \& Rodriguez-Bolívar, 2014; Zhao \& Patten, 2016; For example, CordobaPachon et al. (2014) have found that senior managers in state-owned enterprises show awareness of and commitment to CSR principles through a number of key static elements. Also, a study conducted in China has shown that the managers of state-owned companies almost uniformly see social and environmental reporting as a tool of image enhancement (Zhao \& Patten, 2016). However, these studies did not address the correlation between state ownership (as ownership type) and CSR performance. There is still a research gap in this field, but some of the more recent papers have dealt with this issue. Lopatta et al. (2017) used ownership data and CSR data from 25 different countries and investigated the impacts of controlling shareholders on firms' CSR performance, where the controlling shareholders are defined as a single shareholder who owns more than $50 \%$ of shares in one firm. Their results show that there is a positive relation between state-controlled ownership and the CSR performance of firms, whereas the other types of controlling ownership (banks, industrial firms, institutional investors, and individuals) have no impact on CSR performance.

In fact, one of the major national objectives is sustainable development, which is based on three pillars economic, social and environmental. It may be noted that companies that act responsibly contribute to achieving the goals within all three basic pillars of sustainable development (Stojanovic-Aleksic \& Boskovic, 2016). Compared to the private sector, state-owned companies are faced with various challenges in order to fully accept the strategic CSR, whereby the most important ones refer to managing diverse stakeholders and their interests, support of managers' discretion and community connection (Cordoba-Pachon et al., 2014). Their important stakeholder is "the public" and accomplishment of public policy objectives, such as providing services to society, often becomes the most important issue.

Therefore, their management should be highly motivated to encourage CSR, because, thus, they meet the expectations of different stakeholders, ensuring better living and working conditions in the community from which they draw the necessary resources. Through an active involvement and promotion of socially responsible business, state-owned companies are gaining people's trust, directly enhancing the corporate image and, indirectly, the political position and the power of governance. Also, a study carried out in Serbia in the field of local administration services, shows that customer orientation, which is closely connected to responsibility to customers, greatly affects citizens' satisfaction nowadays (Cicvarić Kostić, Okanović, Milosavljević, \& Vukmirović, 2013). Starting from the all aforementioned motives, we believe that stateowned comapnies care about CSR more than private ones, so the fourth hypothesis is:

H4: State ownership affects CSR.

\section{Data and Methodology}

\subsection{Methods for Data Collection and Processing}

In addition to an overview of the current domestic and foreign literature, and in order to develop an adequate theoretical basis as the starting point, we performed an empirical research by distributing a questionnaire in the period from March to June 2015. The sample consisted of 24 corporations, including 80 respondents, managers of various hierarchical levels in the corporate sector in the Republic of Serbia.

As an instrument for data collection, we used an adapted questionnaire that consists of 30 questions. The empirical studies conducted by Turker (2009), Dam and Scholtens (2012), Oh, et al. (2011), Sánchez, Sotorrío and Díez (2011) and the Serbian Chamber of Commerce were used as a starting point. Renovated structure of the questionnaire is the result of authors' original scientific approach, according to a defined subject and objectives. The first part of the questionnaire includes questions on key CSR dimensions. The respondents answered on the basis of the degree of agreement with the statements, using a five-point Likert 
scale. The second part consists of closed questions about a dominant CSR motive. General information about respondents were collected by the five questions that make up the third part of the original questionnaire, and relate to gender, age, position in the organization, years of service and level of education. Data on the ownership structure is taken from the database, available on the website of the Central Securities Depository of the Republic of Serbia.

Data analysis was performed using relevant methods and techniques of the software Statistical Package for Social Sciences (SPSS) 20.0. We analyzed the structure and characteristics of the sample, using descriptive statistics. Reliability of a scale was analyzed using Cronbach's Alpha coefficient, which amounts to 0.890 , indicating a high degree of reliability, since the questionnaire consists of 30 items. Mann Whitney $U$ test was applied in order to test the hypotheses.

\subsection{Sample}

The sample consists of corporations listed at the Central Securities Depository of the Republic of Serbia. There is a total of 1511 on the list of corporations, but 292 of them are in bankruptcy (), so we excluded those from the sampling procedure. After that, we completely randomly chose 80 companies from the list. However, 20 of them were very small stock companies (less than 10 employees) so they also were excluded because we targeted only large corporations, since small stock companies in Serbia often do not even have corporate governance structure nor CSR policy. Also, CSR in general may significantly vary depending on the size of the company, which is beyond the scope of our investigation. Finally, 233 questionnaires were distributed to the remaining 60 corporations (3 or 4 managers per organization). However, 80 respondents from 24 companies agreed to participate.

As mentioned, the size of all the corporations in the sample is large, but they belong to different industries (energy sector, banking and finance, food industry, manufacturing, agriculture and ICT). The structure of the sample, in terms of ownership structure, is given in Table 1, showing that corporations with ownership concentration are the dominant category (89\% of respondents). Minority ownership category is below $8 \%$, confirming the fact that most companies in Serbia are owned by large shareholders, as a result of methods of privatization applied as in the transition process. In terms of ownership type, $65 \%$ of respondents are managers of privately-owned and $35 \%$ of state-owned companies. ${ }^{2}$ Foreign and domestic ownership are almost equally represented in the sample, given the $43.8 \%$ of respondents from foreign owned corporations, which are all multinational companies.

Table 1: Structure of the sample

\begin{tabular}{lcc}
\hline Ownership concentration & Frequency & Percent \\
\hline More minority owners with the share of $10-30 \%$ & 3 & 3.8 \\
More minority owners with the share of $31-50 \%$ & 6 & 7.5 \\
Majority owner with the share of $51-70 \%$ & 19 & 23.8 \\
Majority owner with the share of $71-90 \%$ & 7 & 8.8 \\
Majority owner with the share of $91-100 \%$ & 45 & 56.3 \\
Total & 80 & 100.0 \\
\hline State ownership & Frequency & Percent \\
\hline $91-100 \%$ & 22 & 27.5 \\
$71-90 \%$ & 6 & 7.5 \\
$31-50 \%$ & 5 & 6.3 \\
Less than 10\% & 47 & 58.8 \\
Total & 80 & 100.0 \\
\hline Foreign ownership & Frequency & Percent \\
\hline $91-100 \%$ & 35 & 43.8 \\
$10-30 \%$ & 5 & 6.3 \\
Less than 10\% & 40 & 50.0 \\
Total & 80 & 100.0 \\
\hline
\end{tabular}

Source: Own research 
Genders are equally represented in the sample (50\% male/famale). The most numerous are the respondents in the age category $36-45$ years (48.8\%) and the sample mainly consists of respondents with 16-25 years of service (38.8\%). As for formal position, operational managers (51.3\%) are dominant in the sample, immediately followed by middle management (42.5\%), while the top management constitutes $6.3 \%$ of the sample.

\section{Results and Discussion}

\subsection{Testing the Normal Distribution of Variables}

In order to carry out further data analysis, the normal distribution of variables was tested by means of Kolmogorov-Smirnov and Shapiro-Walk tests (Table 2). According to the Kolmogorov-Smirnov test, the variables Internal CSR and the overall score of CSR have a normal distribution $(p>0.05)$. However, the Shapiro-Wilk test did not comply with this finding. Since the Shapiro-Wilk test is more stringent, it can be concluded that no variable has normal distribution.

Table 2: Test of normal distribution of variables

\begin{tabular}{lcccccc}
\hline & \multicolumn{2}{c}{ Kolmogorov-Smirnov } & \multicolumn{2}{c}{ Shapiro-Wilk } \\
\hline & Statistic & df & Sig. & Statistic & df. & Sig. \\
\hline Internal CSR & 0.099 & 80 & 0.052 & 0.968 & 80 & 0.043 \\
Customers & 0.119 & 80 & 0.007 & 0.952 & 80 & 0.005 \\
Environment & 0.126 & 80 & 0.003 & 0.968 & 80 & 0.044 \\
Community & 0.207 & 80 & 0.000 & 0.815 & 80 & 0.000 \\
CSR disclosure & 0.138 & 80 & 0.001 & 0.965 & 80 & 0.028 \\
CSR total & 0.090 & 80 & 0.164 & 0.969 & 80 & 0.048 \\
\hline
\end{tabular}

Source: Own research

\subsection{CSR Motives and the Level of CSR}

First, we divided the respondents into three sub-samples depending on the three types of replies that they gave to the question "What are the most important motives for CSR implementation in your company?". Out of the total number of respondents, only 4 respondents answered that the obligatory motives are the most important for CSR implementation in their company. Since this subsample is not representative, the hypothesis H3 cannot be tested. Nevertheless, this result is significant because it implies that obligatory motives are not a frequent reason for corporate social responsibility in Serbia. The remaining respondents opted for motives that belong to the group of instrumental motives (profit, brand, image, competitive advantage), 46 respondents, as well as moral motives (employee satisfaction and moral reasons), 30 respondents.

Since the variables are not normally distributed, we applied nonparametric statistical techniques to test the hypotheses $\mathrm{H} 1$ and $\mathrm{H} 2$. In order to compare statistically significant differences in the level of CSR aspects, measured by the arithmetic mean, between two independent sub-samples, i.e., respondents with dominant instrumental motives and respondents with dominant moral motives, we applied Mann Whitney $U$ test. It was impossible to form sub-samples in which companies would be units of observation, because not the same motives were dominant among all managers of the same company. Therefore, the results are strongly influenced by personal perceptions of respondents, which may represent a limitation of research, but we do not observe it that way because the motives are individual by their nature and it is difficult to talk about the motives of the whole company in terms of CSR because the concept does not only involve strategic decisions, but also a number of individual behaviours, practices, and beliefs.

The most important results of Mann Whitney $U$ test are presented in Table 3 and discussed below. Also, we derived conclusions about the relationship between the CSR motives and the level of CSR development, in accordance with the objectives of the research. 
Table 3: Differences between CSR dimensions depending on CSR motives

\begin{tabular}{|c|c|c|c|c|c|c|c|}
\hline & & $\begin{array}{l}\text { Internal CSR } \\
\text { (Employees) }\end{array}$ & Customers & Environment & Community & $\begin{array}{c}\text { CSR } \\
\text { disclosure }\end{array}$ & $\begin{array}{l}\text { CSR } \\
\text { total }\end{array}$ \\
\hline \multicolumn{2}{|l|}{ Mann-Whitney U } & 460.500 & 590.500 & 641.500 & 672.500 & 595.500 & 649.500 \\
\hline \multicolumn{2}{|l|}{ Wilcoxon W } & 1541.500 & 1671.500 & 1106.500 & 1137.500 & 1060.500 & 1730.500 \\
\hline \multicolumn{2}{|l|}{ Z } & -2.449 & -1.064 & -.518 & -.191 & -1.009 & -.431 \\
\hline \multicolumn{2}{|c|}{ Asymp.Sig. (2-tailed) } & $0.014^{*}$ & 0.287 & 0.605 & 0.848 & 0.313 & 0.667 \\
\hline Instrumental & $\mathrm{N}$ & 46 & & & & & \\
\hline motives & Median & 3.167 & & & & & \\
\hline \multirow{2}{*}{ Moral motives } & & 30 & & & & & \\
\hline & Median & 3.667 & & & & & \\
\hline
\end{tabular}

Statistically significant differences were identified in one out of five observed CSR aspects, namely Internal CSR $(p<0.05)$. Specifically, the level of Internal CSR is higher when managers are predominantly driven by moral motives, such as care for employees' wellbeing and other ethical factors. Thus, the hypothesis $\mathrm{H} 1$ is supported. This finding is in compliance with similar study of Dare (2016) which shows that firms with a dominant moral motive tend to hold a higher commitment to CSR and to involve it in their daily practices and decisions, both strategically and tactically, more than firms with a dominant instrumental motive. The contribution of our finding, however, is reflected in the specification of the internal dimension of CSR, as an area where companies achieve better results, when managers are motivated by moral and ethical factors, rather than instrumental motives. A previous study shows that the factor of internal values has a greater effect on CSR practices than external drivers (Graafland \& Schouten, 2012; Zhu \& Zhang, 2015). If corporate core values both at the manager personal level and the whole corporate level are consistent with CSR, a company would more likely implement CSR practices (Hsu \& Cheng, 2012 as cited in Zhu \& Zhang, 2015, p. 321). Also, moral motives have a potential to influence employees' participation in CSR initiatives (Aguilera et al., 2007).

However, Mann Whitney $U$ test did not reveal that there are statistically significant differences in terms of external CSR aspects (Customers, Environment, Community, CSR disclosure), so we could not find the support for hypothesis $\mathrm{H} 2$.

\subsection{State Ownership and CSR}

In order to compare the statistically significant differences between the two independent sub-samples, namely state-owned and private companies, Mann Whitney $U$ test of independent samples is applied (Table 4). The significant differences are identified in the following areas: Internal CSR $(p=0.006)$, Customers $(p=0.029)$, and CSR total $(p=0.049)$. Medians of the observed differences were calculated.

As for the Internal CSR, respondents from majority state owned companies largely agree with the statements (Median=3.67) compared to respondents from the companies with minority state ownership (Median=3.00). Also, there is a higher level of responsibility to customers in companies with majority state ownership (Median $=4.400$ ) compared to those with minority state ownership (Median=4.000). In addition, there is higher level of CSR in general, in companies with majority state ownership (Median=3.940) compared to those with minority state ownership (Median=3.560).

Table 4: State Ownership and CSR - Results of Mann Whitney U test

\begin{tabular}{|c|c|c|c|c|c|c|}
\hline & $\begin{array}{l}\text { Internal CSR } \\
\text { (Employees) }\end{array}$ & Customers & Environment & Community & $\begin{array}{l}\text { CSR } \\
\text { disclosure }\end{array}$ & CSR total \\
\hline Mann-Whitney U & 455.500 & 513.500 & 565.500 & 590.500 & 695.500 & 532.500 \\
\hline Wilcoxon W & 1833.500 & 1891.500 & 1943.500 & 1968.500 & 1101.500 & 1910.500 \\
\hline Z & -2.759 & -2.178 & -1.646 & -1.420 & -.329 & -1.973 \\
\hline Asymp. Sig. (2-tailed) & 0.006 & 0.029 & .100 & .156 & .742 & .049 \\
\hline Majority state $\mathrm{N}$ & 28 & 28 & 1 & 1 & 1 & 28 \\
\hline $\begin{array}{l}\text { ownership } \\
71-100 \%\end{array}$ & 3.667 & 4.400 & I & I & l & 3.940 \\
\hline Minority & 52 & 52 & 1 & 1 & 1 & 52 \\
\hline $\begin{array}{l}\text { ownership } \\
0-50 \%\end{array}$ & 3.000 & 4.000 & I & I & l & 3.560 \\
\hline
\end{tabular}

Source: Own research 
Based on the results, we can conclude that CSR is higher in two out of five relevant areas when the state is the majority owner. However, the CSR total is higher in state-owned companies than in private ones. Therefore, we conclude that $\boldsymbol{H} \mathbf{4}$ is partially confirmed. This result supports and extends the findings that were obtained in previous studies (e.g., Li \& Zhang, 2010) and primarily refers to a general conclusion about the positive effect of state ownership on CSR. The high level of CSR in state-owned companies might be the reflection of differences in owners' motives as well. As stated above, the specific role of the state as an owner of a company enables greater engagement in the pursuit of broader social interests, in addition to achievement of economic goals. Still, the results indicate the need for state-owned companies to develop more community-related CSR practices, which is also in accordance with previous research (Zhu et al., 2016), as well as environmental and disclosure areas.

It is possible to give a brief overview of the specific Serbian context regarding CSR. Bearing in mind that the CSR concept has only recently become widely accepted and begun to develop in domestic enterprises, it may be noted that government initiatives in this regard lead to positive results. Particular progress the Government of the Republic of Serbia has made in promoting social responsibility is the adoption of the Strategy of development and promotion of corporate social responsibility in Serbia for the period from 2010 to 2015. The importance of the Strategy is reflected in raising awareness of domestic enterprises in terms of social responsibility, not only as an activity within marketing or public relations, but as a long-term strategic orientation that affects sustainable development of the country. In addition, this approach is one of the ways to improve the competitive position of local companies in foreign markets and the chance to achieve superior results. It can therefore be assumed that the state as the majority owner of companies is trying to achieve the goals set at higher levels. Although awareness of the significance of CSR has risen in recent years, CSR is still regarded as a marketing tool and possibly a way to build a reputation (Vukovic, Mihic, Miletic, \& Curcic, 2016). According to Ivanovic-Djukic (2009), a very small number of companies in Serbia have CSR managers and these activities are sometimes coordinated by a finantial director or incorporated in the public relations department. A recent study has shown that the most developed CSR areas vary among different industries (Krstic \& Trbovich, 2015). Namely, they have found that the financial sector places most emphasis on its customers, whilst the construction sector (cement industry) sets the local community and employees in the cornerstone of its business operations, in line with international practice. However, public relations or the marketing sector are primarly engaged with stakeholders' relationships in Serbia. Stojanovic-Aleksic, Eric Nielsen \& Boskovic (2016) have found that banks in Serbia devote more attention to customers and community, while internal CSR and CSR disclosure are on a lower level. Also, CSR performance is generally not included in the reports, so CSR disclosure is still a challenge for both public and private companies in Serbia. This is in line with previous research conducted by Stojanovic-Blab, Blam, \& Spasic, 2016, who show that the level of sustainability reporting by Serbian companies is low and not satisfactory.

\section{Scientific and Practical Implications}

The scientific contribution of the paper is reflected in shedding more light on the importance of understanding the nature of corporate social responsibility and focusing on various CSR drivers, rather than effects solely. The study provides relevant insights into the interdependence of CSR motives and the level of CSR, as well as the level of state ownership and CSR, thus expanding the knowledge base in this field and overcoming the observed gap. These findings provide the basis for identifying strengths and weaknesses in terms of CSR in Serbia, where empirical research in the field of CSR motivation is lacking.

The results have implications for managers as well. One important implication from our analysis is how managers perceive the CSR influence their commitment to the CSR initiatives. Findings help managers understand the antecedents and consequences of their engagement in CSR and contribute to raising the awareness of all the CSR benefits, for the company and for the society, in order both to achieve sustainable competitive position and create value for stakeholders. Considering the importance of the motives for the development of CSR, some of the following steps that the senior management should make must be directed precisely towards educating and motivating the lower levels in terms of CSR, developing positive expectations from the application of this concept, both in terms of a sense of justice to society and personal satisfaction for fulfilment of moral responsibility. CSR scholars have argued for "the importance of employee participation in CSR efforts (Maclagan, 1999, as cited in Aquilera et al., 2007), and it has been suggested that employees' participation in CSR planning, coordination, and decision making can contribute to their 
personal growth" (Aguilera et al., 2006, p. 856). This is an important part of sustainable business and may cause many long-term positive effects that have been discussed in the paper.

The paper provides insights into specific CSR areas where further education and raising awareness about the importance of CSR is necessary. Also, the findings highlight the space for improvement of specific CSR areas in domestic, private and state-owned companies. Since the hypothesis $\mathrm{H} 4$, stating that the level of CSR is higher in state-owned in comparison with private companies, is partially supported in Serbia, we believe that the state should make greater efforts to promote and encourage CSR in private enterprises, for example through subsidies as in the case of China (Lee et al., 2017). Also, policy makers who want to promote firms' CSR performance may consider increasing the state ownership in firms (Lopatta et al., 2017).

\section{Limitations and Future Research}

The inevitable limitations of the research are identified. The first disadvantage stems from the limitations of the survey, as a technique for data collection, primarily from the subjectivity of respondents. This is particularly expressed in this kind of research connected to ethical issues. Second, reluctance of representatives of companies to participate in scientific research demonstrates an underdeveloped cooperation between academic and professional public, which significantly complicates research in the fields of business and management. As a result, the generalizability of the conclusions may be advanced if the sample were larger. Third, similarly to Dare (2016), we included only large firms in the study, so the results may not hold with smaller or private firms. The findings may be supported with further statistical analysis and on a larger and more heterogeneous sample (e.g., in terms of company size and other general characteristics) in future research. Finally, we have not evaluated all the possible CSR motives within the firm, such as top-down influences (Aguilera et al., 2007) or leaders' personal needs for attention and image reinforcement (Petrenko et al., 2016), as we only focused on external obligatory motives, such as pressures from market, NGO's etc. In addition, some firms may engage in CSR based on resource availability, rather than motive (Dare, 2016).

As new knowledge always leads to new relevant questions, the results of this study also encourage new ideas. In future research, it would be interesting to analyze these issues in more detail, considering the interdependence between motives, as well as other factors, besides state ownership, that mediate the observed relationship. Also, general characteristics of companies, other than state-ownership might affect the observed relationship between CSR motives and the level of CSR. That should be further explored in future studies. Due to the fact that the sample was drawn from one specific area, this research could be extended to other countries in order to make comparative analysis and to improve the generalizability of the conclusions.

\section{Conslusion}

This paper argues that the choice of which CSR areas to commit to, depends on the corporate motivation for such engagement. The results are consistent with the initial proposal that if moral motives are dominant, the company will be more committed to internal CSR (responsibility to employees). However, we did not find the answer to the questions of which CSR areas are more developed when CSR is seen either as an instrument for achieving other market or financial goals or as an obligation. The most important finding of this research is that responsibility towards employees is more developed if the managers have adopted CSR as a value system based on morality and philanthropy, than if they use CSR as a wealth enhancing mechanism. This relationship is significant because it may enhance the employee motivation in general, as well their willingness to engage in other CSR areas (Aguilera et al., 2007).

The results also show that CSR in general, internal CSR and responsibility towards customers are more developed in state-owned compared to private companies. Having in mind the results and the previous discussion in regard of $\mathrm{H} 4$, we can conclude that the belief that the state bears most of the responsibility for the society still dominates in Serbia, whereas the private sector, probably due to lack of incentives or the lack of awareness about the importance of social responsibility is lagging behind in this regard. Nevertheless, management of state-owned companies should adopt a broader and more systemic approach to CSR, by developing awareness about the importance of environmental protection for sustainable 
business development (Kong, Liu, \& Dai, 2014; Schaltegger \& Figge, 2000) and greater involvement in this field. Also, since the so called social reporting leads to multiple benefits such as positive effects on the financial performance and value (Carnevale, 2012), they should make a step forward and accept the GRI guidelines, based on the triple bottom line, which in addition to economic performance, encompass the reporting on social and environmental performance.

\section{Acknowledgements}

Parts of this paper have been presented at the XV International Symposium SYMORG 2016 "Reshaping the future through sustainable business development and entrepreneurship", Zlatibor, Serbia, 2016.

\section{REFERENCES}

[1] Aguilera, R.V., Rupp, D. E., Williams, C. A. \& Ganapathi, J. (2007). Putting the S back in corporate social responsibility: a multilevel theory of social change in organizations, Academy of Management Review, 32(3), 836-863. DOI: 10.2139/ssrn.567842

[2] Aguilera, R.B., Williams C.A., Conley, J.M., \& Rupp, D.E. (2006). Corporate Governance and Social Responsibility: a comparative analysis of the UK and the US. Corporate Governance: An International Review, 14(3), 147-158. DOI: 10.1111/j.1467-8683.2006.00495.x

[3] Bowen, H. R. (1953). Social Responsibilities of the Businessman. NewYork: Harper\&Row.

[4] Brunton, M., Eweje, G., \& Taskin, N. (2015). Communicating Corporate Social Responsibility to Internal Stakeholders: Walking the Walk or Just Talking the Talk?, Business Strategy and the Environment, 9999: DOI 10.1002/bse.1889.

[5] Carnevale, C., Mazzuca, M., \& Venturini, S. (2012). Corporate Social Reporting in European Banks: The Effects on a Firm's Market Value, Corporate Social Responsibility and Environmental Management, 19(3), 159-177. DOI: 10.1002/csr.262

[6] Carroll, A. B. (1991). The Pyramid of Corporate Social Responsibility: Toward the Moral Management of Organizational Stakeholders. Business Horizons, 34(4), 39-48.

[7] Carroll, A.B. (1999). Corporate social responsibility - evolution of a definitional construction. Business and Society, 38(3), 268-295. DOI: 10.1016/j.redee.2015.11.002

[8] Centralni registar hartija od vrednosti,

[9] Cicvaric Kostic, S., Okanovic, M., Milosavljevic, M., \& Vukmirovic, J. (2013). Antecedents of Citizens' Satisfaction with Local Administration in Serbia, Transylvanian Review of Administrative Sciences, 40E, 22-34.

[10] Commission Of the European Communities, (2001). Green Paper - Promoting a European framework for Corporate Social Responsibility, Brussels.

[11] Cordoba-Pachon J.-R., Garde-Sanchez R., \& Rodriguez-Bolívar M.P. (2014). A Systemic View of Corporate Social Responsibility (CSR) in State-Owned Enterprises (SOEs). Knowledge and Process Management, 21 (3), 206-219. DOI:

[12] Curcic, R. D., Miletic, L. Z., \& Bjegovic, M. J. (2016). Contrasting of CSR strategies self-presentations and consumers expectations in Serbia. Industrija, 44(1), 151-166. DOI:10.5937/industrija1-10104

[13] Dam, L., Scholtens, B. (2012). Does Ownership Type Matter for Corporate Social Responsibility. Corporate Governance: An International Review, 20(3), 233-252. DOI:10.1111/j.1467-8683.2011.00907.x

[14] Dare, J. (2016). Will the Truth Set Us Free? An Exploration of CSR Motive and Commitment. Business and Society Review, 121(1), 85-122. DOI: 10.1111/basr.12082

[15] Davis, K. (1967). Understanding The Social Responsibility Puzzle. Business Horizons, 10(4), 45-50.

[16] Devinney, T.M. (2009). Is the Socially Responsible Corporation a Myth? The Good, the Bad, and the Ugly of Corporate Social Responsibility. Academy of Management Perspectives, 23(2), 44-56. DOI: 10.5465/AMP.2009.39985540

[17] European Commission, (2011), Communication from the Commission to, the European Parliament, the Council, the European Economic and Social Committee and the Committee of the Regions, Brussels: EUR- Lex(Official Journal of the European Communities).

[18] Fernandez Sanchez, J.L., Sotorrio, L.L., \& Diez, E.B. (2011). The Relationship Between Corporate Governance and Corporate Social Behavior: A Structural Equation Model Analysis, Corporate Social Responsibility and Environmental Management, 18(2), 91-101. DOI: 10.1002/csr.244 
[19] Freeman, R.E. (1984). Strategic Management: A stakeholder approach. Boston: Pitman.

[20] Garriga, E. \& Mele D. (2004). Corporate Social Responsibility Theories: Mapping the Territory. Journal of Business Ethics, 53(1-2), 51-71. DOI 10.1023/B:BUSI.0000039399.90587.34

[21] Gibson, K. (2000). The Moral Basis of Stakeholder Theory. Journal of Business Ethics, 26 (3), 245-257. DOI: $10.1023 / \mathrm{A}: 1006110106408$

[22] Graafland, J. \& Schouten, C. (2012). Motives for corporate social responsibility. De Economist, 160 (4), 377-396. DOI: 10.1007/s10645-012-9198-5

[23] Gray, R., Kouhy, R., \& Lavers, S. (1995). Corporate Social and Environmental Reporting: A Review of the Literature and a Longitudinal Study of UK Disclosure. Accounting, Auditing and Accountability Journal, 8(2), 47-77. DOI:10.1108/09513579510146996

[24] Hawn, O. \& loannou, I. (2016). Mind the gap: The interplay between external and internal actions in the case of corporate social responsibility. Strategic Management Journal, 37(13), 2569-2588. DOI: $10.1002 /$ smj.2464

[25] Hsu, J. \& Cheng, M. (2012). What prompts small and medium enterprises to engage in corporate social responsibility? A study from Taiwan. Corporate Social Responsibility and Environmental Management, 19 (5), 288-305. DOI: 10.1002/csr.276

[26] Ivanovic-DJukic, M. (2010), Promovisanje drustveno odgovornog poslovanja preduzeca u Srbiji, Sociologija, 53(1), 21-42.

[27] Koh, H.C. \& Boo, E.H.Y. (2004). Organizational ethics and employee satisfaction and commitment. Management Decision, 42(5), 677-693. DOI: DOI:10.1108/00251740410538514

[28] Kong, D., Liu, S., \& Dai, Y. (2014). , Corporate Social Responsibility and Environmental Management, 21(2), 100-112. DOI: 10.1002/csr.1306

[29] Kotler, P. \& Lee, N. (2005). Korporativna drustvena odgovornost - uciniti najbolje za svoju kompaniju i za izabrani drustveni cilj. Beograd: Hesperia.

[30] Krstic, N. \& Trbovich, A. S. (2015). Stakeholder management in Serbia's CSR practice. Ekonomika preduzeća, 63(5-6), 279-292. DOI:10.5937/ekopre1506279K

[31] Kuo, L., Yeh, C., \& Yu, H. (2012). Disclosure of Corporate Social Responsibility and Environmental Management: Evidence from China, Corporate Social Responsibility and Environmental Management, 19, 273-287.

[32] Lee, E., Walker, M., \& Zeng, C. (2017). Do Chinese state subsidies affect voluntary corporate social responsibility disclosure?, Journal of Accounting and Public Policy, 36(3), 179-200. DOI:10.1016/j.jaccpubpol.2017.03.004

[33] Li, W. \& Zhang, R. (2010). Corporate Social Responsibility, Ownership Structure and Political Interference: Evidence from China, Journal of Business Ethics, 96 (4), 631-645. DOI: 10.1007/s10551. 010-0488-z

[34] Lopatta, K., Jaeschke, R., and Chen, C. (2017) Stakeholder Engagement and Corporate Social Responsibility (CSR) Performance: International Evidence. Corporate Social Responsibility and. Environmental Management, 24, 199-209. DOI: 10.1002/csr.1398.

[35] Margolis, J. D., Elfenbein, H. A., \& Walsh, J. P. (2007). Does it pay to be good? A meta-analysis and redirection of research on corporate social and financial performance (Working Paper). Boston: Harvard Business School

[36] Martínez, P. \& Rodríguez del Bosque, I. (2013). CSR and customer loyalty: The roles of trust, customer identification with the company and satisfaction, International Journal of Hospitality Management, 35, 89 - 99. DOI:10.1016/j.ijhm.2013.05.009

[37] McWilliams, A. \& Siegel, D. (2001). Corporate Social Responsibility: A Theory of the Firm Perspective. Academy of Management Review, 26(1), 117-127. DOI: 10.5465/AMR.2001.4011987

[38] Mohd Ghazali, N.A. (2007). Ownership structure and corporate social responsibility disclosure:some Malaysian evidence. Corporate Governance: The international journal of business in society, 7 (3), 251266. http://dx.doi.org/10.1108/14720700710756535

[39] Munilla, L. S. \& Miles, M. P. (2005). The Corporate Social Responsibility Continuum as a Component of Stakeholder Theory. Business and Society Review, 110(4), 371-387. DOI: 10.1111/j.00453609.2005.00021.x

[40] Oh, W.Y., Chang, Y.K., \& Martynov, A. (2011). The Effect of Ownership Structure on Corporate Social Responsibility: Empirical Evidence from Korea, Journal of Business Ethics, 104 (2), 283-297. DOI: 10.1007/s10551-011-0912-z

[41] Onkila, T. (2015). Pride or Embarrassment? Employees' Emotions and Corporate Social Responsibility. Corporate Social Responsibility and Environmental Management, 22(4), 222-236. DOI: $10.1002 /$ csr.1340. 
[42] Pérez, A. \& Rodríguez del Bosque, I. (2015). How Customer Support for Corporate Social Responsibility Influences the Image of Companies: Evidence from the Banking Industry, Corporate Social Responsibility and Environmental Management, 22 (3), 155-168. DOI: 10.1002/csr.1331

[43] Petrenko, O. V., Aime, F., Ridge, J., \& Hill, A. (2016). Corporate Social Responsibility or CEO Narcissism? CSR Motivations and Organizational Performance. Strategic Management Journal, 37(2), 262-279. DOI: $10.1002 / \mathrm{smj} .2348$

[44] Porter, M. \& Kramer, M. (2006). Strategy and Society - The Link between Competitive Advantage and Corporate Social Responsibility. Harvard Business Review, 84(12), 78-92.

[45] Sánchez, J. L. F., Sotorrío, L. L., \& Díez, E. B. (2011). The Relationship Between Corporate Governance and Corporate Social Behavior: a Structural Equation Model Analysis, Corporate Social Responsibility and Environmental Management, 18(2), 91-101. DOI: 10.1002/csr.244

[46] Schaltegger, S. \& Figge, F. (2000). , Corporate Social Responsibility and Environmental Management, 7(1), 29-42. DOI: 10.1002/(SICI)1099-0925(200003)7:1<29::AID-EMA119>3.0.CO;2-1

[47] Skudiene, V. \& Auruskeviciene, V. (2012). The contribution of corporate social responsibility to internal employee motivation. Baltic Journal of Management, 7 (1), 49-67.

[48] Stankevicienë, J. \& Cepulytë, J. Sustainable value creation: coherence of corporate social responsibility and performance of socially responsible investment funds. Economic Research, 27 (1), 882-898. DOI:10.1080/1331677X.2014.976058

[49] Stjepcevic, J. \& Siksnelyte, I. (2017). Corporate Social Responsibility in Energy Sector. Transformations in Business \& Economics, 16(1-40), 21-33.

[50] Stojanovic-Aleksic, V. \& Boskovic, A. (2015). Corporate Social Responsibility: The Experience of Serbia and the European Union. In M. Jaksic, V. Stojanovic Aleksic, \& P. Mimovic (Eds.), Economic and social aspects of Serbia joining the European Union (255-268), Kragujevac: Faculty of Economics.

[51] Stojanovic-Aleksic, V. \& Boskovic, A. (2016). Evolution and the importance of the CSR concept. In V. Lekovic (Ed.), Institutional Changes as the Determinant of Serbian Economic Development (403 - 420), Kragujevac: Faculty of Economics.

[52] Stojanović-Aleksić, V., Eric-Nielsen, J., \& Boskovic, A. (2016). Social responsibility in the banking sector: Experience from Serbia. Bankarstvo, 45(2), 34-55. DOI:10.5937/bankarstvo1602034S

[53] Stojanovic-Blab, M., Blab, D., \& Spasic, D. (2016). Sustainability reporting - a challenge for Serbian companies. Themes, 40(4), 1349. doi:10.22190/TEME1604349S

[54] Surroca, J., Tribo,J.A., \& Waddock, S. (2010). Corporate responsibility and financial performance: the role of intangible resources. Strategic Management Journal, 31 (5): 463 - 490. DOI: 10.1002/smj.820

[55] Turker, D. (2009). Measuring Corporate Social Responsibility: A Scale Development Study. , 85(4), 411427. DOI:10.1007/s10551-008-9780-6

[56] Virvilaite, R. \& Daubaraite, U. (2011). Corporate Social Responsibility in Forming Corporate Image. Engineering Economics, 22 (5), 534-543. DOI:10.5755/j01.ee.22.5.972

[57] Vlastelica Bakic, T., Cicvaric Kostic, S., \& Neskovic, E. (2015). Model for Managing Corporate Social Responsibility. Management: Journal of Sustainable Business and Management Solutions in Emerging Economies , 74, 47-56. DOI:10.7595/management.fon.2015.0002

[58] Vukovic, A., Mihic, S., Miletic, L., \& Curcic, R. (2016). Corporate Social Responsibility as a part of Corporate Public Relations in Serbia. Industry / Industrija, 44(4), 159. DOI:10.5937/industrija44-12689

[59] Zhao, N. \& Patten, D. (2016). An exploratory analysis of managerial perceptions of social and environmental reporting in China: Evidence from state-owned enterprises in Beijing, Sustainability Accounting, Management and Policy Journal, 7 (1), 80-98, DOI:10.1108/SAMPJ-10-2014-0063

[60] Zhu, Q. \& Zhang, Q. (2015). Evaluating practices and drivers of corporate social responsibility: the Chinese context. Journal of Cleaner Production, 100 (1) 315-324. DOI:10.1016/j.jclepro.2015.03.053

[61] Zhu, Q., Liu, J., \& Lai, K. (2016). Corporate social responsibility practices and performance improvement among Chinese national state-owned enterprises. International Journal of Production Economics, 171 (3), 417-426. DOI:10.1016/j.ijpe.2015.08.005 


\section{$1 / 1 / 1 / 1 / 1 / 1 / 1 / 1 / 1 / 1 / 1 / 1 / 1 / 1 / 1 / 1 /$ abouthe euthor}

\section{Vesna Stojanović-Aleksić \\ University of Kragujevac, Faculty of Economics, Serbia vesnasa@kg.ac.rs}

Vesna Stojanović-Aleksić, PhD, is an Associate Professor at the Department for Management and Business Economics. She holds a PhD degree from the Faculty of Economics in Kragujevac and teaches the following subjects at the same university: Organization of Enterprise, Organizational Behaviour and Leadership. Her research areas are: leadership, organizational culture, organizational change and organizational behaviour. She has published dozens of scientific papers.

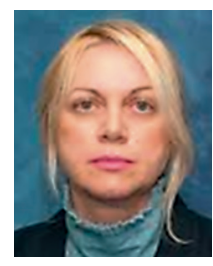

Aleksandra Bošković

University of Kragujevac, Faculty of Economics, Serbia aboskovic@kg.ac.rs

Aleksandra Boskovic, MSc, is a Teaching Assistant at the Department for Management and Business Economics. She graduated and completed her master studies at the

Faculty of Economics, University of Kragujevac. Currently, she is a PhD student at the same university. She teaches the following courses: Organization of Enterprise and Customer Behaviour. The areas of her research interest are: organizational design, organizational change and corporate social responsibility. 